\title{
MILKWEED: THE MONARCH'S PRAIRIE HOST
}

\section{ANNA LEIGHTON, 328 Saskatchewan Crescent West, Saskatoon, SK S7M OA4}

Milkweed has a Jekyll and Hyde image over much of its range. Its useful role as the Monarch butterfly's host plant lives in the shadow of its reputation as a killer of livestock. In Saskatchewan, however, where milkweed is not a problem for livestock and Monarchs are scarce, this plant is poorly known.

This article introduces our five native milkweed species. It complements what we know about the Monarch butterfly in Saskatchewan (see article, this volume) by describing the distribution and characteristics of these unusual and distinctive members of our flora.

Two species, Silky and Whorled Milkweed are rare plants restricted to the southeast corner of the province. The other three, Green, Low and Showy Milkweed, occur widely in the grassland and adjacent parkland (scientific names for all five are given below). A sixth species, Swamp Milkweed (Asclepias incarnata) was reported to occur "Throughout Canada to the Saskatchewan" by Thomas Drummond, a naturalist with John Franklin's second overland expedition in 1825$1827,{ }^{7}$ but this species remains undocumented west of south-central Manitoba. All but Whorled Milkweed have been noted as host plants for Monarch caterpillars in the Prairie Provinces. ${ }^{1,5}$

The Milkweeds Opposite simple leaves and milky juice set most of Saskatchewan's milkweeds apart from our other wildflowers except Dogbane (Apocynum androsaemifolium), Indian Hemp (Apocynum cannibinum) and possibly some of the spurges (Euphorbia sp.). Milkweeds differ from all other plants in their flower structure and pods.

The flowers are unmistakable. The petals are turned back at maturity and where the petals ought to be there are five hollow structures called hoods (b, Fig. 1). These surround the anthers and pistil which are fused together to form a flattopped, round column called the gynostegium. In all our species, except Green Milkweed, a "horn" arises from within each hood (d, Fig. 1) and arches toward this central column. The flowers occur in showy, colourful heads, as in Silky and

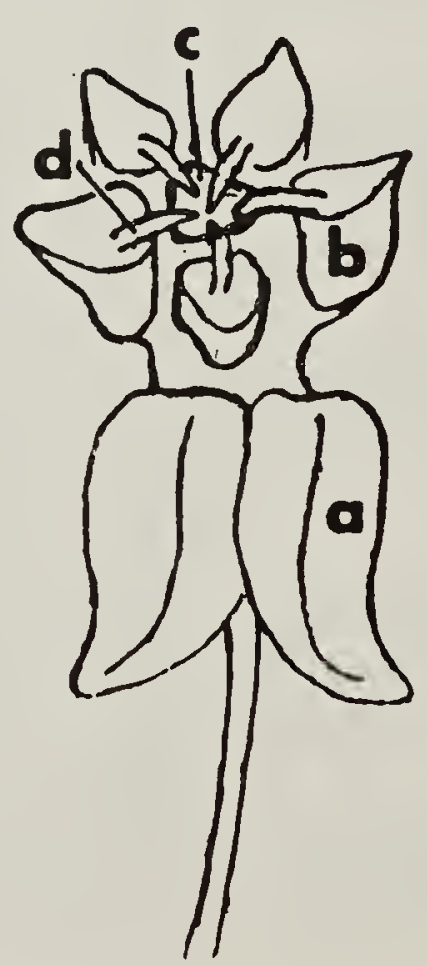

Figure 1. Milkweed flower, showing petals (a), hoods (b), gynostegium (c) and horns (d). 


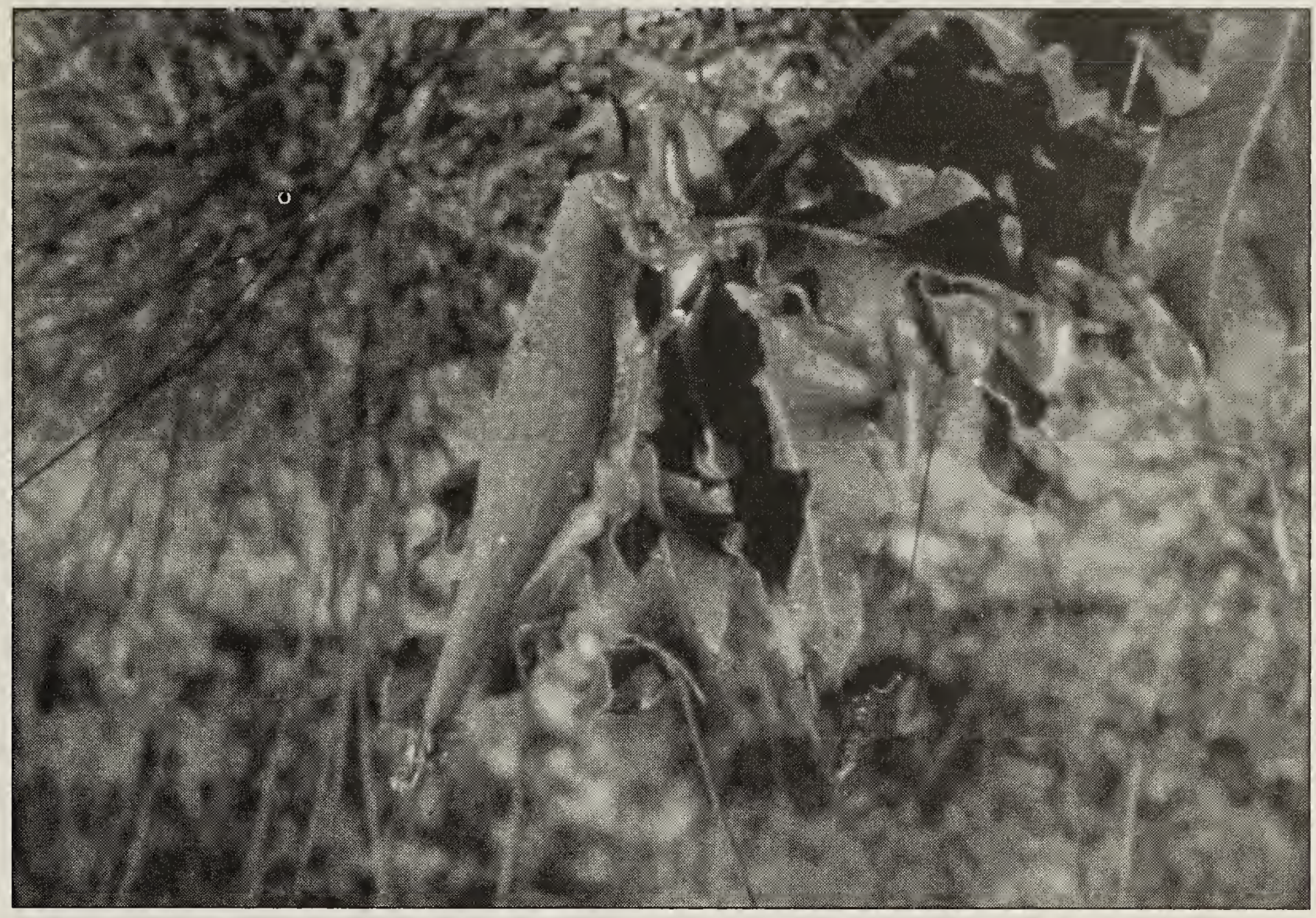

Figure 2. Unripe pod of Green Milkweed

Anna Leighton

Showy Milkweed or in inconspicuous, pale-coloured clusters, as in the other species. In spite of the large number of flowers per head, most plants produce only a few pods per year.

Milkweed pods (Fig. 2) are inflated and thin-walled, and contain hundreds of round, flat seeds. In areas where Silky Milkweed is common, the pods are much enjoyed by children for the tightly packed rows of seeds which burst forth, each with its own parachute, when the pods are opened. The empty pods are silky smooth inside and, according to Anna Comstock, they "snapped shut so easily, we imprisoned therein bumblebees 'to hear them sing'...". ${ }^{3}$ In contrast, Apocynum species have pencil-thin, woody, brown pods. These often persist on the previous year's stalks among the flowering plants.

The following descriptions of Saskatchewan's native milkweed species are derived from four major references on the plants of our area. ${ }^{6,9,10,12}$ Information felt to be regionally variable, such as flowering date, habitat, population size and height of the smaller species, is based on Saskatchewan specimens housed in the W.P. Fraser Herbarium at the University of Saskatchewan, as are the locations shown on the distribution maps.

Green Milkweed Asclepias viridiflora (Map 1). Green Milkweed is the only Saskatchewan species that lacks horns (some taxonomists place it in the genus Acerates, for this reason). It has compact, golf-ball sized clusters of greenish flowers (Fig. 3) and a coarse, untidy appearance due to irregularly spaced, thick leaves with somewhat wavy margins and a rough hairiness over the entire plant.

This low plant (most are $20-37 \mathrm{~cm}$ high) grows on dry prairie hillsides, sandhills and stabilized sand dunes. It flowers from late June to the third week in July, with occasional late flowerings (12 August 1960). 


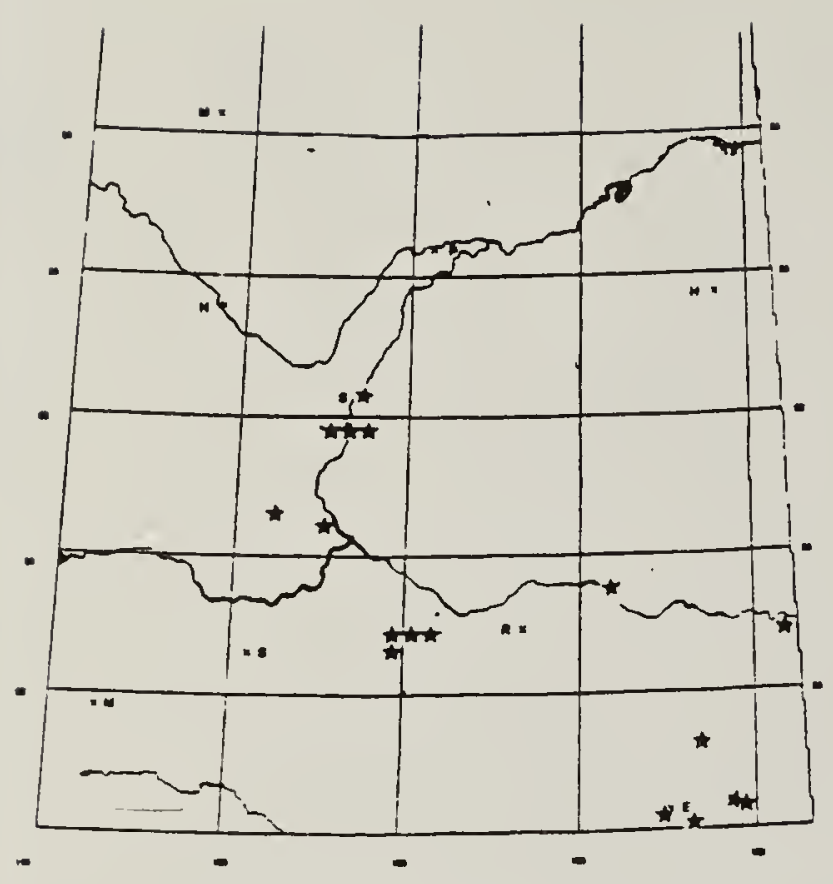

MAP 1 : GREEN MILKWEED

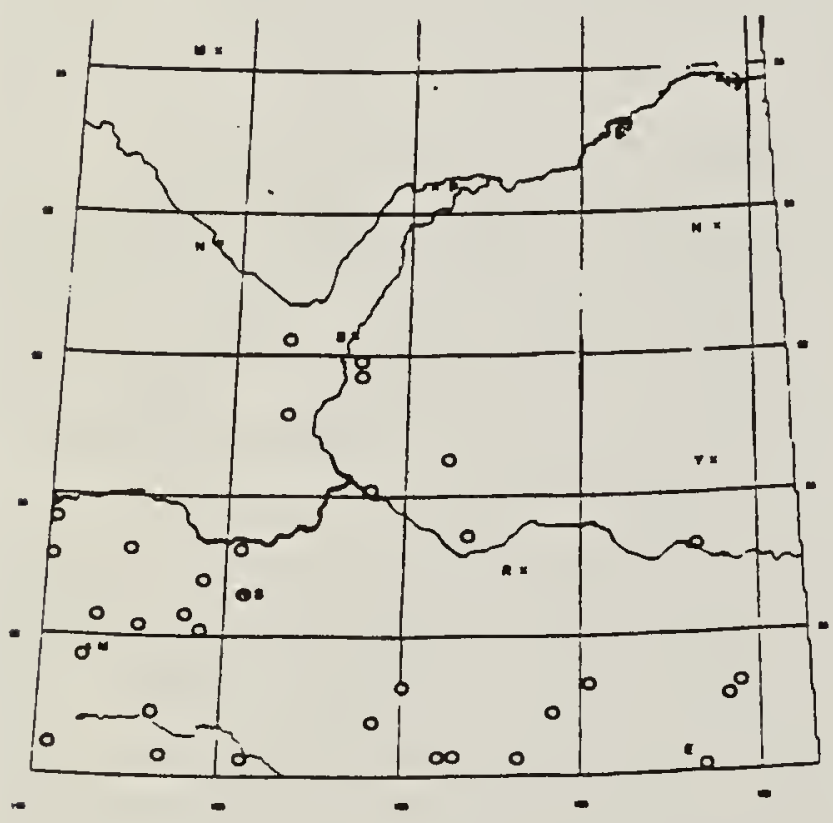

MAP 3 : SHOWY MILKWEED

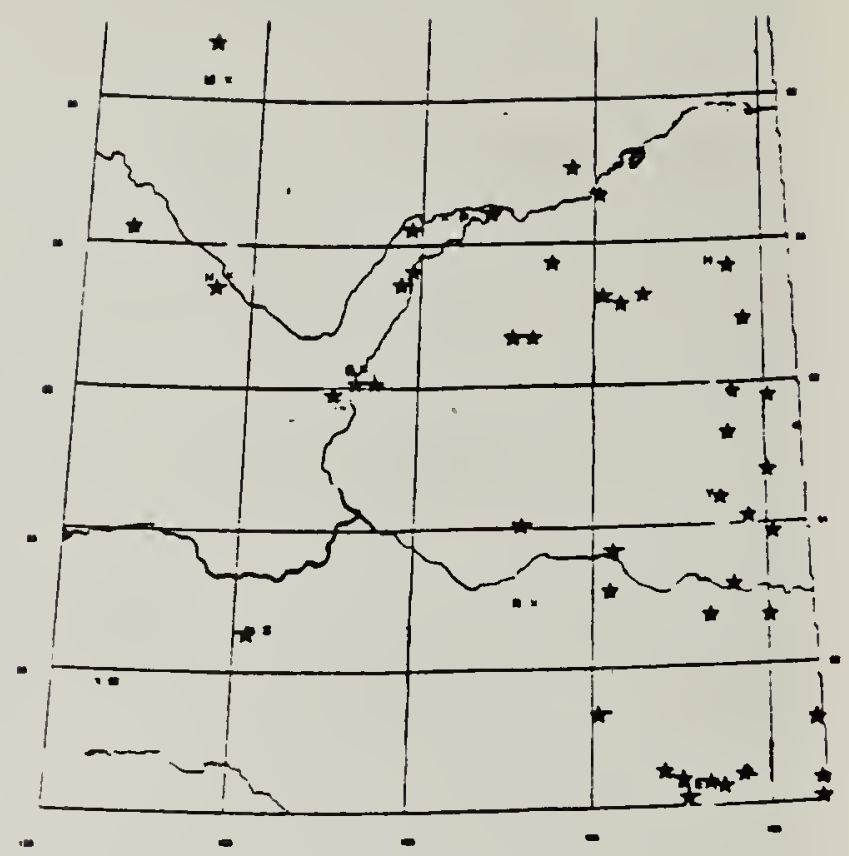

MAP 2 : LOW MILKWEED

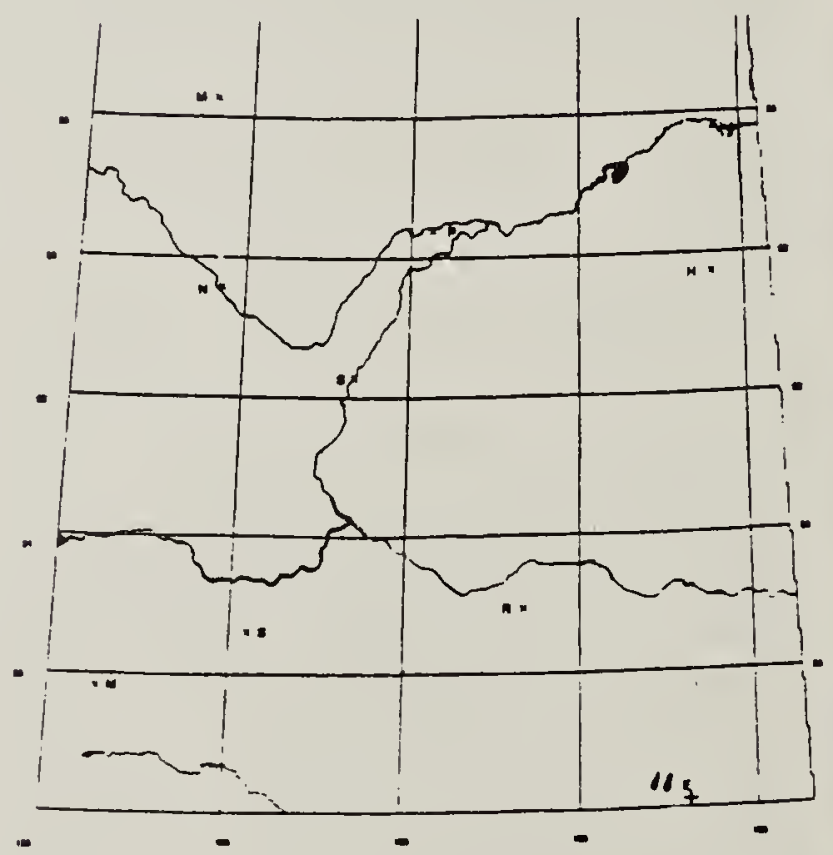

MAP 4 : SILKY MILKWEED + WHORLED MILKWEED ।

Map 1 (top left): Green Milkweed. Map 2 (top right): Low Milkweed. Map 3 (bottom left): Showy Milkweed. Map 4 (bottom right): Silky Milkweed, Whorled Milkweed. $E=$ Estevan; $H=$ Hudson Bay; $M=$ Meadow Lake (54\%); $M=$ Maple Creek $\left(49^{\circ}\right) ; N=$ North Battleford; $R=$ Regina; $S=$ Saskatoon $\left(52^{\circ}\right) ; S=$ Swift Current $\left(50^{\circ}\right) ; Y=$ Yorkton. 


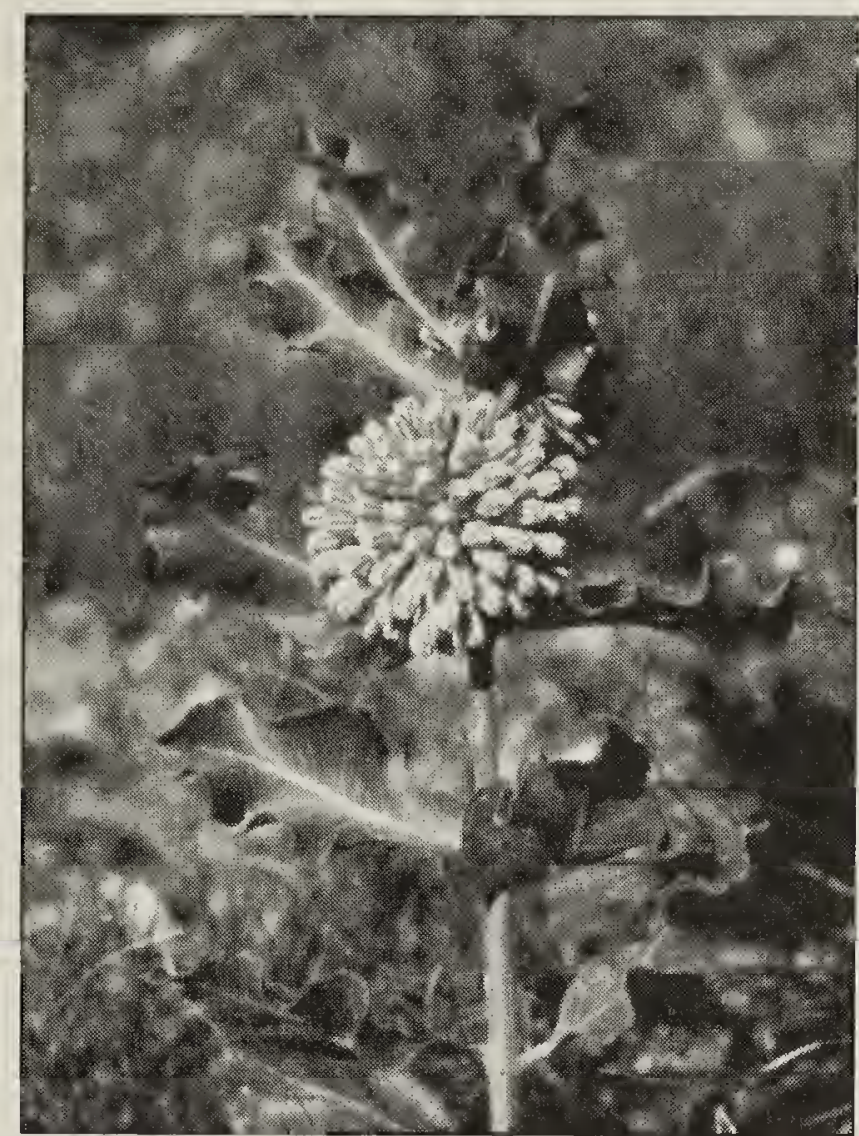

Figure 3. Green Milkweed

Jim Romo

Green Milkweed leaves vary in shape from ovate to linear. The narrow-leaved variety, Asclepias viridiflora var. linearis, is common in the Saskatoon-Dundurn area.

Saskatchewan has the most widespread population of Green Milkweed of any province in Canada. This species is considered rare in Alberta and Ontario, and uncommon in Manitoba. It also occurs in B.C. and extensively in the Great Plains south of the border, east to $\mathrm{New}$ England and south to Georgia and New Mexico.

\section{Low Milkweed (Dwarf or Oval-} leaved Milkweed) Asclepias ovalifolia (Map 2). Although called Low Milkweed, in Saskatchewan this species is taller (most are $30-47 \mathrm{~cm}$ ) than Green and Whorled Milkweed. In contrast to Green Milkweed, this plant has a tidy appearance. The plants are slender, less hairy and the leaves are symmetrical and regularly spaced along the stem. Of all our milkweeds, this one looks most like Dogbane.

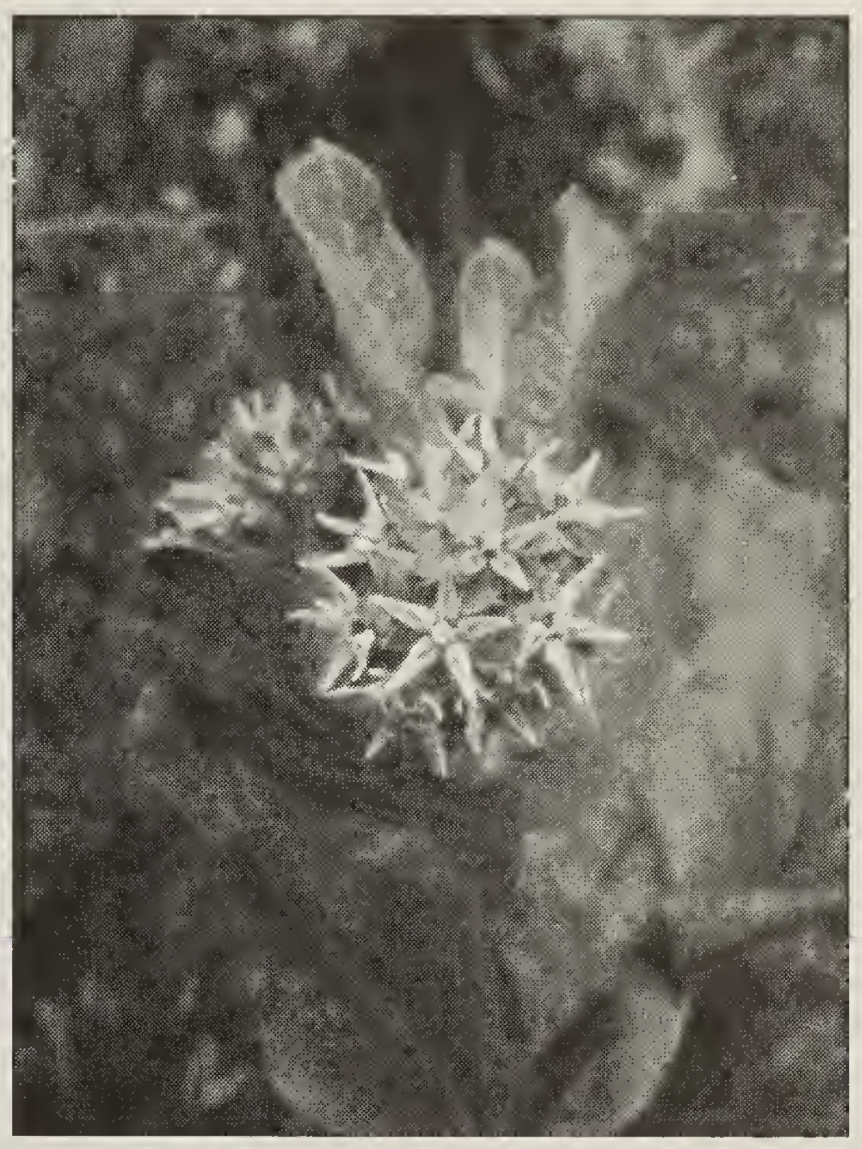

Figure 4. Showy Milkweed

Jim Romo

The flowers are greenish-white to pale yellow and the main cluster grows from the tip of the plant. If there are other clusters, these arise lower down on the stem at the base of the upper leaf stalks. The small number of flowers (4-20) on long stalks give the flower clusters an open and delicate appearance. (See photograph p. 223. ${ }^{15}$ )

This is the second most common milkweed in Saskatchewan where it grows in a wide variety of habitats: moist prairie, slopes of all aspects, creek banks, tops of levees and low hills, edges of wetlands and bluffs, and forest clearings. The principal flowering period is mid-June to midJuly, with 3 June 1980 and 2 August 1954, being the extremes recorded. Populations may consist of scattered individuals but this species often grows in patches, the largest one recorded for Saskatchewan being 125 m square, noted by John Hudson at Pike Lake, 14 July 1968.

Low Milkweed is a plant of the northern plains; it occurs primarily in the prairie provinces and the northern 


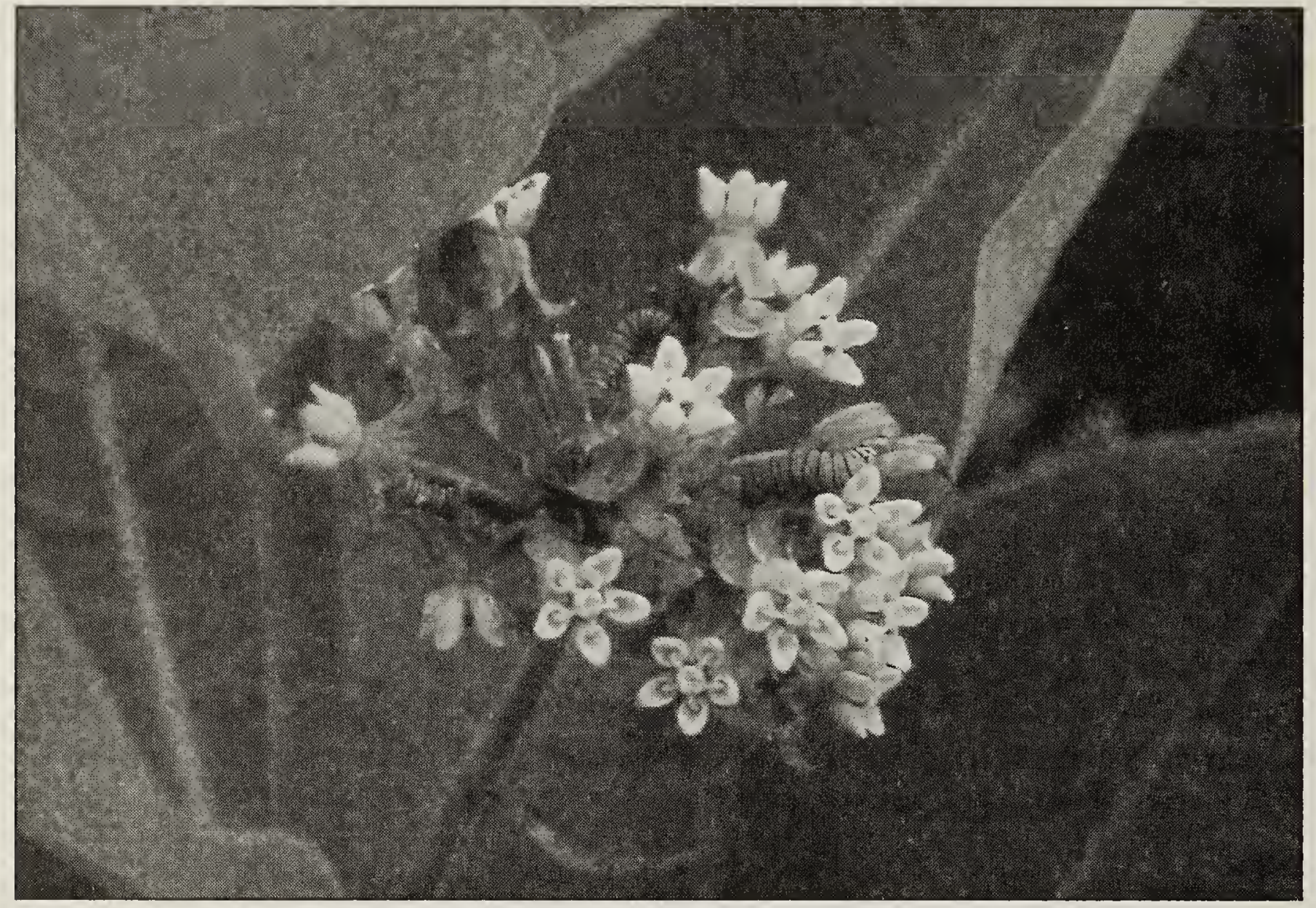

Figure 5. Monarch caterpillars eating Silky Milkweed flowers

Anna Leighton

prairie states (east to Illinois). Other locations in Canada are northwestern Ontario and southeastern B.C.

Showy Milkweed Asclepias speciosa (Map 3). Showy Milkweed is a coarse plant with broad leaves and robust heads of $10-40$ large $(1-2 \mathrm{~cm})$ flowers (Fig. 4). Most of our plants are fuzzy with a dense coat of fine, matted hairs. The flowers are rosepurple and have tapering hoods at least $1 \mathrm{~cm}$ long. Another distinctive feature of this species is that the base of the leaves, where they attach to the leaf stalks, are rounded, sometimes even heart-shaped, rather than tapered.

This is the most common milkweed species in Saskatchewan. It is a medium sized plant $(30-100 \mathrm{~cm})$ which grows along roadsides and railways, on disturbed ground and in moist habitats such as lake shores, creek banks and flood plains. Spreading by underground roots, Showy Milkweed can form large patches on abandoned land. A patch near Tessier described by John Hudson on 27 July 1985 was "a solid stand about 1 acre" (0.4 ha).

The main flowering period is late June to the end of July, with June 23 the earliest recorded date. The fragrant flowers have a reputation for causing drowsiness in people and insects.

Showy Milkweed is a western species both in Canada (southern B.C. to southern Manitoba) and the United States (west of the Mississippi River).

This species may be difficult to distinguish from Silky Milkweed. The most reliable characteristic is the length and shape of the hood. Showy hoods are more than $10 \mathrm{~mm}$ long and start to taper about halfway along their length. Silky hoods are less than $8 \mathrm{~mm}$ long and taper little if at all. ${ }^{4}$

Silky Milkweed (Common Milkweed) Asclepias syriaca (Map 4). Although Silky Milkweed tends to be 
taller than Showy Milkweed, it is less coarse in appearance, having a narrower stem, narrower leaves and a thinner coat of hair. The plants are ornate, with multiple heads of up to 130 delicate purplish flowers on slender stalks (Fig. 5). The Saskatchewan population begins to flower in early July.

In Saskatchewan, this plant is known from only one site - a pasture in the Souris River Valley near Pinto. John Richardson, who travelled through Saskatchewan in the early 1800 s, noted that the Canadian range of this plant was "Canada to the Saskatchewan." This may suggest that Silky Milkweed was more widespread in Saskatchewan at that time. ${ }^{7}$ Saskatchewan is at the northwestern edge of this plant's extensive range in Canada (east to Nova Scotia) and in eastern, central and southwestern United States.

Although a rare plant in Saskatchewan, Silky Milkweed is common and abundant over much of its range, forming large patches in meadows, fields and waste places and along roads and railroads. It is the principal host plant of the Monarch in Canada and the milkweed most familiar to people in northeastern North America. Because of its ability to aggressively invade disturbed ground, it is classed as a noxious weed in Nova Scotia, Ontario, Manitoba and Saskatchewan. Only Nova Scotia and Manitoba have active control programs however: there are too many plants to control in Ontario. ${ }^{16}$ In Saskatchewan, Silky Milkweed is a protected rare plant and is listed in the province's 1984 Noxious Weed Act (under the name Common Milkweed).

Whorled Milkweed Asclepias verticillata (Map 4). This rare Saskatchewan plant looks completely unlike our other milkweeds: the leaves are very narrow $(0.5-1.5 \mathrm{~mm})$ and short $(30-70 \mathrm{~mm})$ and are attached to the stem in groups of three to six (an arrangement called whorled or verticillate) (Fig. 6). The pods are narrow and attached to the stem by upright stalks instead of stalks turned down as in our other milkweed species ( cf. Fig. 2). This is the shortest milkweed in Saskatchewan: most plants are between 14 and $37 \mathrm{~cm}$ tall, with a maximum height of $45 \mathrm{~cm}$.

The habitat is varied, including slopes (dry south-facing slopes and moister sites in coulees), mixedgrass prairie and the bottom of the Souris River valley. The plant occurs as scattered individuals or, rarely, in colonies.

The flowering dates on the herbarium specimens are 19 and 20 July and 4 and 23 August. The clusters of small, numerous, whitish flowers arising near the top of this slender plant make it look, from a distance, more like Northern Bedstraw than the other Saskatchewan milkweeds.

The Saskatchewan population is at the northwestern edge of this plant's range. Whorled Milkweed also grows in southern Manitoba and southern Ontario and increases in abundance southward across the border into the northern Great Plains, extending eastward to New England and south to Texas.

Whorled Milkweed is the most toxic milkweed in Saskatchewan but, like all milkweeds, it is unpalatable and animals eat it only when nothing else is available.

\section{Simple Key to Flowering Saskatchewan Milkweeds}

Flowers pink-purple (very occasionally white in Silky Milkweed)

- hoods at least $11 \mathrm{~mm}$ long Showy Milkweed 
- hoods at most $8 \mathrm{~mm}$ long - Silky Milkweed

Flowers greenish-white, creamy or yellow

- leaves whorled - Whorled Milkweed

- leaves opposite: horn present Low Milkweed; horn absent Green Milkweed

$@$ NOIND = Milkweed and Butterflies Milkweeds are prolific nectar producers and many of our butterflies visit the flowers for food, including the Great Spangled Fritillary, Delaware Skipper and the Monarch. ${ }^{1}$

The milkweed plant, especially the milky juice, is toxic to most insects and the only caterpillar that feeds on the plant itself is the Monarch's. These caterpillars consume the poisonous milkweed unharmed and use the toxins, which they store in various tissues, to deter avian predators and possibly insect parasites. ${ }^{13}$

Milkweed toxins are cardiac glycosides called cardenolides. They occur in all stages of the Monarch's life, starting with the eggs, which may contain sufficient cardenolides that only 74 of them can make a
Blue Jay sick. When the larvae hatch, they feed on milkweed leaves, buds and flowers, gathering and storing cardenolides. In addition to storing chemicals as a deterrent, they can spurt out cardenolide-rich fluid when provoked. The chemicals are found in the pupae and the adults as well. Wild butterflies contain anywhere from no cardenolides to ten times the dose required to make a Blue Jay sick, depending on which species of milkweed the larvae fed upon. ${ }^{2}$

A description of a Blue Jay's reaction to these chemicals illustrates why they are powerful deterrents: "The effects of cardenolides ... include retching, vomiting, excessive bill-wiping, alternate fluffing and flattening of feathers, erratic movements about the cage, head and wing jerking, partial eye closure and a generally sick appearance."

Cardenolides from different milkweed species have different chemical compositions. Using these chemicals, researchers have been able to determine the species of milkweed that Monarchs feed on during migration and this has helped

\begin{tabular}{|c|c|c|c|c|c|c|c|}
\hline Species & $\begin{array}{c}\begin{array}{c}\text { Flowering } \\
\text { dates }\end{array} \\
\end{array}$ & $\begin{array}{l}\text { Flower } \\
\text { colour }\end{array}$ & $\begin{array}{l}\text { \# of } \\
\text { flowers/ } \\
\text { head }\end{array}$ & Height & $\begin{array}{c}\begin{array}{c}\text { Leaf } \\
\text { arrangement }\end{array} \\
\end{array}$ & $\begin{array}{l}\text { Range in } \\
\text { Canada }\end{array}$ & $\begin{array}{l}\text { Unique } \\
\text { feature }\end{array}$ \\
\hline Low & $\begin{array}{l}\text { mid-June to } \\
\text { mid-July } \\
\text { (June 3, } \\
\text { August } 2\end{array}$ & $\begin{array}{l}\text { greenish } \\
\text { white - pale } \\
\text { yellow }\end{array}$ & $4-20$ & $\begin{array}{l}30-47 \mathrm{~cm} \\
(15 \mathrm{~cm}, 60 \\
\mathrm{cm})^{\star}\end{array}$ & $\begin{array}{l}\text { opposite to } \\
\text { sub-opposite }\end{array}$ & $\begin{array}{l}\text { S.E. BC to } \\
\text { N.W. ON }\end{array}$ & $\begin{array}{l}\text { main flower } \\
\text { cluster at tip } \\
\text { of stem }\end{array}$ \\
\hline Green & $\begin{array}{l}\text { late June to } \\
\text { 3rd week of } \\
\text { July } \\
\text { (August 12) }\end{array}$ & green & $20-80$ & $\begin{array}{l}20-37 \mathrm{~cm} \\
(15 \mathrm{~cm}, 40 \\
\mathrm{cm})^{\star}\end{array}$ & $\begin{array}{l}\text { opposite to } \\
\text { alternate }\end{array}$ & $\begin{array}{l}\text { S.E. BC to } \\
\text { ON }\end{array}$ & lacks horn \\
\hline Showy & $\begin{array}{l}\text { late June to } \\
\text { late July }\end{array}$ & rose-purple & $10-40$ & $30-100 \mathrm{~cm}$ & opposite & $\begin{array}{l}\mathrm{S} . \mathrm{BC} \text { to } \mathrm{S} \text {. } \\
\mathrm{MB}\end{array}$ & $\begin{array}{l}\text { hoods } 11 \\
\mathrm{~mm} \text { or } \\
\text { longer }\end{array}$ \\
\hline Silky & $\begin{array}{l}\text { early June } \\
\text { to? }\end{array}$ & $\begin{array}{l}\text { rose-purple } \\
\text { (white) }\end{array}$ & $20-130$ & $60-200 \mathrm{~cm}$ & opposite & $\begin{array}{l}\text { S.E. SK to } \\
\text { NS }\end{array}$ & $\begin{array}{l}\text { hoods less } \\
\text { than } 8 \mathrm{~mm}\end{array}$ \\
\hline Whorled & $\begin{array}{l}\text { mid-July to } \\
\text { mid-August } \\
?\end{array}$ & $\begin{array}{l}\text { greenish- } \\
\text { white }\end{array}$ & 6-20 & $\begin{array}{l}14-37 \mathrm{~cm} \\
(45 \mathrm{~cm})^{\star}\end{array}$ & whorled & $\begin{array}{l}\text { S.E. SK to } \\
\text { ON }\end{array}$ & $\begin{array}{l}\text { linear, } \\
\text { whorled } \\
\text { leaves }\end{array}$ \\
\hline
\end{tabular}


understand migration patterns. ${ }^{8}$ When Monarchs leave their wintering sites in Mexico, the females fly into southern United States and lay eggs on milkweed species that flower there in early spring. Adults reared on these plants arrive in Saskatchewan in June to lay their eggs on our milkweeds. The butterflies raised here migrate back to Mexico to spend the winter.

Milkweeds are excellent plants for butterfly gardens. All our native species should survive as perennials in Saskatchewan gardens. Species from outside our area may not overwinter. Milkweeds establish well from seeds, bought or collected, and from young plants. ${ }^{14}$ To control the spread of plants in and around the garden, the seed pods must be removed before they ripen. Otherwise the abundant seeds burst from the pods and disperse widely on the wind.

Toxicity The chemicals that protect Monarchs from birds are toxic to livestock when milkweed is consumed directly. Cardenolides consumed at doses much lower than fatal ones will cause an animal to vomit, thus averting poisoning. Some animals, however, such as sheep which cannot vomit, can be poisoned by consuming as little as $0.2 \%$ of their body weight of dried milkweed. ${ }^{11}$

Surprisingly little research has been done on the milkweed cardenolides, but it is known that some act on the nervous system, others on the digestive system and all affect the heart. ${ }^{11}$ Cardenolide concentration, and therefore toxicity, is greatest in milkweed species with narrow leaves and in southern plants - either species with a southern distribution or southern populations of widespread species such as Showy Milkweed. Whorled Milkweed

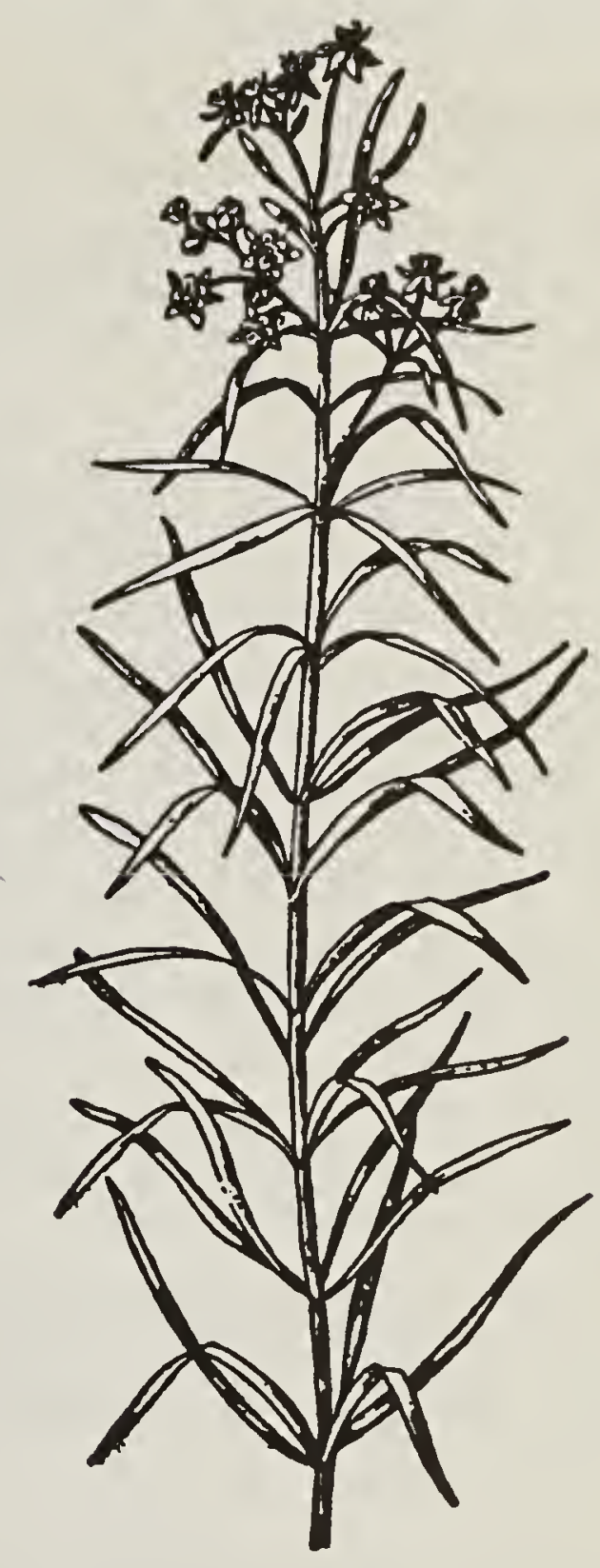

Figure 6. Whorled Milkweed (source: Gleason, Henry A. 1952. The New Britton and Brown Illustrated Flora of the Northeastern United States and Adjacent Canada. Vol. 3. The New York Botanical Garden.)

is Saskatchewan's only narrowleaved milkweed and our most toxic species, affecting both the nervous system and the heart when ingested by sheep in small doses. Whether the other species native to Saskatchewan are toxic to livestock is unclear from the literature.

Acknowledgements I would like to thank Bernie Gollop and Vernon Harms for assistance with this article; Jean Timpa, of the Blomidon Naturalists Society, N.S., for identification of milkweed species from my photographs; and Jim Romo for pro- 
viding two of the illustrations.

The author welcomes information from readers on Saskatchewan milkweeds and can be reached by email (leighton@sk.sympatico.ca) as well as through the address at the beginning of this article.

1. BIRD, C.D., G.J. HILCHIE, N.G. KONDLA, E.M. PIKE, F.A.H. SPERLING. 1995. Alberta butterflies. Provincial Museum of Alberta, Edmonton.

2. BROWER, L.P. 1984. Chemical Defenses in butterflies. Pages 109-134 in: R.I. Vane-Wright and P.A. Ackery, eds., The biology of butterflies. Academic Press, Toronto.

3. COMSTOCK, A.B. 1947. Handbook of nature-study. Comstock Publishing, Ithaca, NY.

4. HARMS, V.L. and R.M. DUNBAR. 1989. The Silky Milkweed in Saskatchewan. Blue Jay 47: 2-6.

5. KLASSEN, P., A.R. WESTWOOD, W.B. PRESTON, W.B. MCKILLOP. 1989. The butterflies of Manitoba. Manitoba Museum of Man and Nature, Winnipeg.

6. LOOMAN, J. and K.F. BEST. 1979. Budd's flora of the Canadian prairies. Agriculture Canada, Ottawa

7. MACOUN, J. 1883. Catalog̉ue of $\mathrm{Ca}-$ nadian plants.

8. MALCOLM, S.B., B.J. COCKRELL, and L.P. BROWER. 1992. Spring recolonization of eastern North America by the Monarch Butterfly: successive brood or single sweep migration? In: Stephen B. Malcolm and My- ron P. Zalucki, eds., Biology and conservation of the Monarch Butterfly, No. 38 Science Series, Natural History Museum of Los Angeles County.

9. MCGREGOR, R.L., T.M. BARKLEY and the GREAT PLAINS FLORA ASSOCIATION. 1986. Flora of the Great Plains. University Press of Kansas, Lawrence.

10. MOSS, E.H. 1983. Flora of Alberta. Second edition. University of Toronto Press, Toronto.

11. OGDEN, Lanell et al. 1991. Experimental intoxication in sheep by Asclepias. Pages 495-499 in: L.F. James et al., eds. Poisonous Plants. lowa State University Press, Ames.

12. SCOGGAN, H.J. 1979. The flora of Canada. National Museums of Canada, Ottawa.

13. SMITH, D.A.S. 1978. Cardiac glycosides in Danaus chrysippus (L.) provide some protection against an insect parasitoid. Experimentia 34 (7): 844-5.

14. SWENGEL, Ann. 1993. Milkweed mania in the midwest. American Butterflies, May 1993: 10-16

15. VANCE, F.R., J.R. JOWSEY and J.S. MCLEAN. 1984. Wildflowers across the Prairies. Western Producer Prairie Books, Saskatoon.

16. WHITE, David J. 1996. Milkweeds of Canada.www.MonarchWatch.org/ canada/ weed/1.htm

In all things of nature there is something of the marvellous. Aristotle 